\title{
Kajian Dampak Ekonomi Hutan Desa Terhadap \\ Pendapatan Petani Kampung Merabu \\ (Kabupaten Berau, Provinsi Kalimantan Timur)
}

\author{
Juliansyah Roy ${ }^{1}$, Mudrajad Kuncoro ${ }^{2}$, Dio Caisar Darma ${ }^{3}$ \\ Fakultas Ekonomi \& Bisnis, Universitas Mulawarman \\ Fakultas Ekonomika \& Bisnis, Universitas Gadjah Mada \\ Sekolah Tinggi Ilmu Ekonomi Samarinda
}

\author{
$\llbracket$ Corresponding Author: \\ Nama Penulis: Juliansyah Roy \\ E-mail: juliansyah.roy@feb.unmul.ac.id
}

\begin{abstract}
The purpose of this study is to answer the prior problems of analyzing the extent to which the effect of the duration of the decision letter is accepted, the size of the land, the number of labor, the transportation costs, the input costs, the partnership pattern, the knowledge of the status of the village forest, the participation of planning and implementation participation, and the participation of monev on farmer income in Merabu. The research method used in this research is explorative and analytical descriptive. In general, there is an increase in production, income and employment. Regression analysis proves that the length of the decision letter is accepted and the amount of labour has a positive effect on income significantly. Meanwhile, labour is a dominant variable affecting the income of Merabu. Since the status of village forests is published in 2014, farmers are beginning to transform to manage and utilize forest land. The number of workers had increased quite drastically from before and after the village forest decree received.
\end{abstract}

Keywords: Farmer Income, village forest, Kampung Merabu

Abstrak: Tujuan dari penelitian ini adalah untuk menjawab masalah sebelumnya yaitu menganalisis sejauh mana pengaruh lama SK diterima, luas lahan, jumlah tenaga kerja, biaya transpor, biaya input, pola kemitraan, pengetahuan status HD, partisipasi perencanaan, partisipasi pelaksanaan dan partisipasi monev terhadap pendapatan petani di Merabu. Metode penelitian yang digunakan dalam penelitian ini adalah eksploratif dan analisis deskriptif. Secara umum, ada peningkatan produksi, pendapatan, dan lapangan kerja. Analisis regresi membuktikan bahwa lama SK diterima dan jumlah tenaga kerja memiliki pengaruh positif terhadap pendapatan secara signifikan. Sementara itu, tenaga kerja merupakan variabel dominan yang mempengaruhi pendapatan Merabu. Sejak status hutan desa diterbitkan pada 2014, petani mulai berubah untuk mengelola dan memanfaatkan lahan hutan. Jumlah pekerja telah meningkat secara drastis dari sebelum dan sesudah luas hutan desa diterima. 
Juliansyah Roy, Mudrajad Kuncoro, Dio Caisar Darma

Kata kunci: Pendapatan Petani, Hutan desa, Kampung Merabu

\section{Cara mencitasi:}

Roy, J., Kunccoro, M., Darma, D. C. (2019). Kajian Dampak Ekonomi Hutan Desa Terhadap Pendapatan Petani Kampung Merabu (Kabupaten Berau, Provinsi Kalimantan Timur). Iqtishoduna. Vol. 15 (2): pp. 197-216.

\section{Pendahuluan}

Perhutanan sosial adalah sistem pengelolaan hutan lestari yang dilaksanakan dalam kawasan hutan negara atau hutan hak/hutan adat yang dilaksanakan oleh masyarakat setempat atau masyarakat hukum adat sebagai pelaku utama meningkatkan kesejahteraannya, keseimbangan lingkungan dan dinamika sosial budaya dalam bentuk Hutan Desa (HD), Hutan Kemasyarakatan (HKm), Hutan Tanaman Rakyat (HTR), Hutan Adat (HA), dan Kemitraan Kehutanan.

Ruang lingkup perhutanan sosial mencakup 5 jenis hutan, yaitu: (1) hutan desa; (2) hutan kemasyarakatan; (3) hutan tanaman rakyat; (4) kemitraan kehutanan; dan (5) hutan adat. Sampai dengan akhir pemerintah SBY (Oktober 2014), rakyat yang memperoleh izin/hak atas kelima jenis hutan ini hanya 449,1 ribu ha atau hanya sekitar 4\% dari total izin/hak yang dikeluarkan oleh pemerintah. Hingga Desember 2017, di bawah Kabinet Kerja Jokowi, kini sudah 4.150 unit SK izin/hak diberikan kepada 293.367 kepala keluarga dengan luasan hutan mencapai 1,336 juta ha.

Sebagai tindak lanjut, pemerintah mengeluarkan kebijakan terbaru yaitu Peraturan Menteri Lingkungan Hidup dan Kehutanan no. 83 tahun 2016 tentang Perhutanan Sosial sebagai revisi atas peraturan-peraturan program perhutanan sosial sebelumnya (tahun 2014). Dalam Permen LHK ini dijelaskan secara rinci mengenai skema perhutanan sosial, mulai dari penyederhanaan mekanisme proses usulan sampai dengan terbitnya izin.

Dengan melalui terbitnya peraturan perhutanan sosial dan adanya beberapa perubahan kebijakan diharapkan dapat merealisasikan target RPJMN tahun 2015-2019 di era kepemimpinan Presiden Joko Widodo terkait Pemberian Akses Kelola Kawasan Hutan oleh masyarakat seluas 12,7 juta ha. Mengingat program perhutanan sosial ini mempunyai kontribusi terhadap perekonomian nasional melalui pengurangan kemiskinan pada tingkat rumah tangga kelompok tani pengelola hutan.

Pasca terbitnya Peraturan Menteri Kehutanan RI No: P/49/MenhutII/2020 tanggal 25 Agustus 2008 jo P. 14/Menhut-II/2010 tanggal 29 Maret jo p. 53/Menhut-II/2011 tanggal 6 Juli 2010 tentang Hutan Desa, serta Keputusan Menteri Kehutanan No: 28/Menhut-II/2014 tanggal 9 Januari 2014 tentang Penetapan Areal Kerja Hutan Kampung Merabu seluas 8.245 hektar di 
Kajian Dampak Ekonomi Hutan Desa...

Kecamatan Kelay, Kabupaten Berau diharapkan status kawasan hutan telah ditetapkan sebagai wilayah hutan desa adalah hutan lindung seluas 8.205 hektar dan hutan produksi terbatas (HPT) sebesar 40 hektar menurut Peta Penunjukkan Kawasan Hutan dan Perairan Provinsi Kalimantan Timur.

Data terakhir dari BPS Kabupaten Berau (2016) menunjukkan jika Produk Domestik Regional Bruto (PDRB) atas dasar harga konstan di Kabupaten Berau tahun 2015 mencapai 26.081,42 juta rupiah (laju pertumbuhan ekonomi (5,07\%), dimana pertanian, kehutanan dan perikanan menjadi sektor tertinggi kedua setelah pertambangan dan penggalian dalam menyumbang jumlah PDRB sebesar Rp 2.400,72 juta atau memiliki pertumbuhan tertinggi dibanding sektor lainnya yaitu 10,36\%. Ini tidak terlepas dari kontribusi sektor tersebut, serta pendapatan per kapita penduduknya mencapai Rp 119,53 juta. Dengan kata lain, dominan penduduk Kabupaten Berau, khususnya di wilayah Kampung Merabu telah mengandalkan sektor tersebut dan masuk kategori kelas bawah.

Masyarakat di Kampung Merabu mayoritas bekerja sebagai petani. Banyaknya jumlah masyarakat yang bekerja di sektor pertanian ini sebagai mata pencaharian, dengan bekerja sebagai petani sudahkah mampu untuk memenuhi kebutuhan hidupnya. Pendapatan para petani merupakan permasalahan yang perlu untuk diperhatikan, sebab pendapatan petani akan berpengaruh terhadap kesejahteraannya. Hal ini akan menyebabkan tingkat kemiskinan khususnya di kalangan petani, jika pendapatan para petani kurang diperhatikan (Pemerintah Kampung Merabu, 2017).

Pemberian status Hutan Desa (HD) kepada petani Kampung Merabu, artinya memberikan kepastian hak pengelolaan hutan bagi petani, terutama dalam hak pengelolaan luasan lahan yang selama ini telah mereka garap (persil). Kepastian hak pengelolaan ini secara ekonomi memberikan nilai tambah bagi aset penerima SK HD terutama aset tanah dan ladang pertanian serta perkebunan. Adanya kepastian kepemilikan aset ini diharapkan dapat meningkatkan semangat berproduksi tanpa merasa khawatir bahwa apa yang petani lakukan melanggar hukum.

HD Merabu merupakan hutan lindung dengan sebagian besar berupa tanaman kayu banggeris. Anggota HD belum mendapatkan hasil dari tanaman pokok padi ladang, karena seluruh hasil usaha tani digunakan untuk konsumsi sendiri. Namun, para petani memperoleh hasil dari tanaman sampingan dan beternak. Di wilayah Kampung Merabu telah dikembangkan kawasan desa wisata alam (Danau Nyadeng, adopsi pohon, jalur tracking), wisata prasejarah (Gua Beloyot), wisata gardu pandang (Doko'an Lemku), dan wisata pendidikan (Perpustakaan Kerima Puri). Kawasan desa wisata tersebut dikelola oleh "Lembaga Kerima Puri", yang tadinya merupakan Lembaga Pengelola HD (LPHD) dan kini menjadi BUMDes. Sebagian anggota HD Tani Merabu umumnya tidak terlibat secara langsung dalam kegiatan desa wisata 
Juliansyah Roy, Mudrajad Kuncoro, Dio Caisar Darma

tersebut karena keterbukaan informasi dan sosialisasi dari aparatur pemerintahan masih kurang. Akibatnya, tidak timbul efek pengganda dari kegiatan wisata tersebut untuk mendorong peningkatan pendapatan masyarakat dan penyerapan tenaga kerja. Sebagian anggota HD Kampung Merabu banyak yang tidak memperoleh tambahan penghasilan.

Tujuan kajian ini dimaksudkan untuk: (1) Menganalisis sejauh mana pengaruh lama SK diterima; luas lahan; jumlah tenaga kerja; biaya transpor; biaya input; pola kemitraan; pengetahuan status HD; partisipasi perencanaan dan partisipasi pelaksanaan; serta partisipasi monev terhadap pendapatan petani Merabu. (2) Menganalisis variabel yang berpengaruh dominan terhadap pendapatan petani Merabu.

\section{Kajian Pustaka}

Pertanian merupakan sektor terbesar hampir dalam setiap ekonomi di negara berkembang. Dalam pembangunan nasional, sektor pertanian diharapkan mampu memberikan peran yang lebih besar kepada petani dalam menentukan prioritas komoditas usaha pertanian yang menjadi usaha andalan negara Indonesia. Suatu usaha tani yang dilaksanakan secara terpadu pada dasarnya adalah untuk meningkatkan pendapatan petani agar dapat menghidupi seluruh keluarganya sekaligus meningkatkan kesejahteraan petani tersebut (Mubyarto, 1990). Tujuan petani dalam melaksanakan usaha taninya adalah untuk memperoleh produksi yang tinggi dengan biaya yang rendah (Adilaga, 1993).

Pendapatan petani saat ini merupakan masalah yang sangat serius, karena banyak penduduk yang tinggal di desa yang bergerak di sektor pertanian. Pendapatan petani berasal dari hasil produksi pertanian yang diolah oleh para petani. Dalam upaya peningkatan pendapatan petani padi, luas lahan sangat berpengaruh untuk dapat meningkatkan tingkat pendapatannya, selain luas lahan yang berpengaruh dalam meningkatkan pendapatan petani, yaitu tenaga kerja dan penguasaan tentang teknologi juga menjadi berpengaruh terhadap tingkat pendapatan.

Peningkatan produksi akan berorientasi pada peningkatan pendapatan petani dan merupakan sisi lain dari pembangunan ekonomi. Dari peningkatan inilah diharapkan terbentuk suatu masyarakat yang sejahtera dan mempunyai kelayakan hidup. Dalam meningkatkan produksi dipengaruhi dari banyak faktor baik dari dalam diri petani sendiri maupun faktor luar. Faktor dari dalam diri petani, yaitu kurangnya keterampilan petani dalam bidang pertanian yang mampu menciptakan berbagai inovasi. Kurangnya ilmu mengenai pertanian secara baik sehingga tanaman yang dihasilkan petani hanya monoton, dan kurangnya modal sehingga mempengaruhi peningkatan produksi. Selain dari faktor dari dalam diri petani itu sendiri. 
Kajian Dampak Ekonomi Hutan Desa...

Ada juga faktor dari luar, yaitu seperti: banjir, kekeringan dan lain-lain yang menyebabkan produksi kadang-kadang sedikit, atau bahkan gagal panen, sehingga pendapatan petani menjadi berkurang.

Penelitian ini ditunjang oleh Damanik (2014) mengungkapkan bahwa variabel luas lahan dan variabel biaya produksi berpengaruh positif dan signifikan terhadap pendapatan petani padi. Sedangkan variabel jumlah tenaga kerja memiliki pengaruh tetapi tidak signifikan terhadap pendapatan petani padi di Kecamatan Masaran, Kabupaten Sragen. Saran yang berkaitan dalam hasil penelitian ini yaitu hendaknya para petani padi dapat meningkatkan produktivitasnya dengan memanfaatkan segala faktor-faktor produksi yang dimilikinya secara efisien. Hendaknya pengelolaan tanaman padi dilaksanakan lebih baik lagi dengan cara melakukan pergantian tanaman pada lahan agar kesuburan lahan tetap terjaga dan menyediakan lumbung padi pasca panen.

Sementara itu, studi terdahulu dilakukan oleh Lin dan Ying (2010). Hasil menunjukkan bahwa faktor umum yang mempengaruhi pendapatan petani adalah faktor produksi pertanian, faktor reproduksi, faktor penggunaan informasi, dan faktor output. Saat ini, tingkat pendidikan petani dan kemampuan petani dalam menangkap informasi memiliki dampak yang relatif besar pada pendapatan petani, dan secara efektif dapat meningkatkan pertumbuhan pendapatan petani.

Kerangka konsep merupakan suatu frame yang akan digunakan dalam penelitian ini. Pada penelitian ini, kerangka teori dibentuk dari beberapa teori dan penjelasan teori yang situsional dan menjelaskan bahwa pendapatan petani di Kampung Merabu dapat dipengaruhi oleh beberapa faktor. Adapun kerangka konsep pada penelitian ini dapat digambarkan sebagai berikut: 
Juliansyah Roy, Mudrajad Kuncoro, Dio Caisar Darma

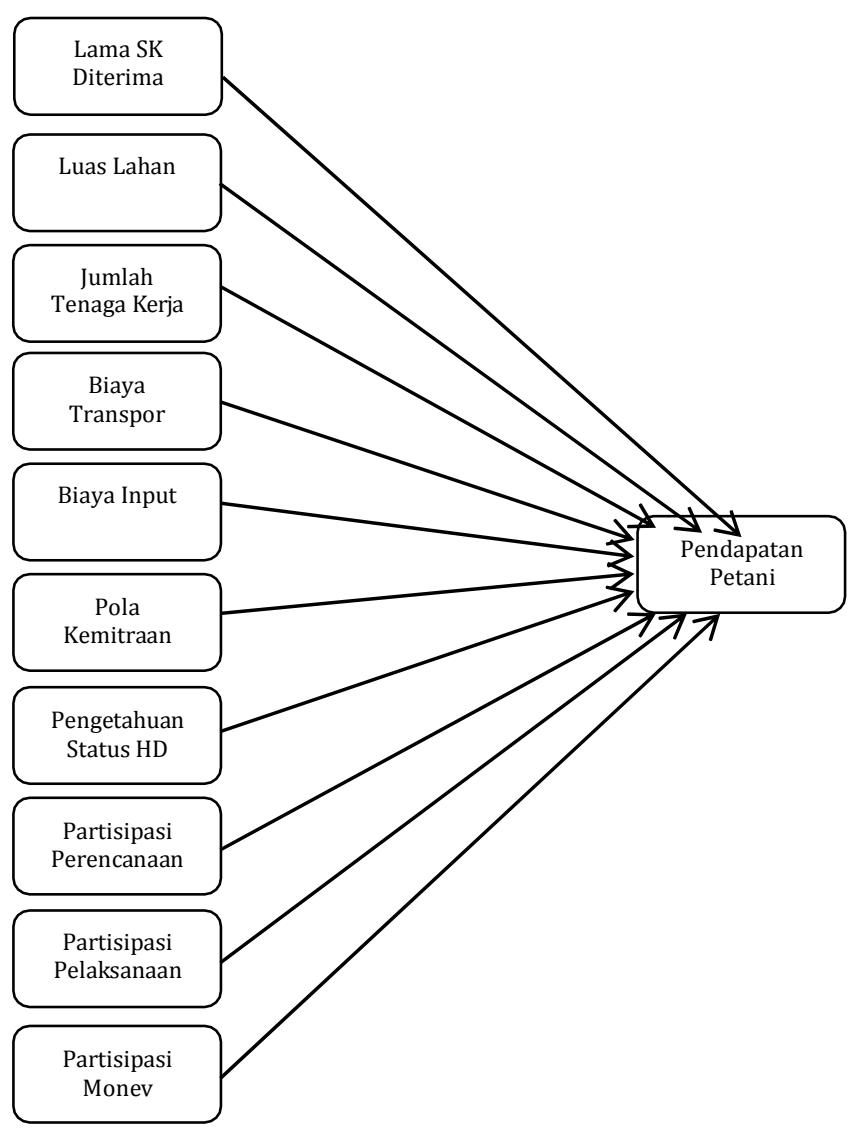

\section{Gambar 1.Kerangka Konseptual}

Berdasarkan uraian sebelumnya, maka dapat ditarik hipotesis penelitian sebagai berikut :

H1. Lama SK diterima berpengaruh positif terhadap pendapatan petani secara signifikan.

H2. Luas lahan berpengaruh positif terhadap pendapatan petani secara signifikan.

H3. Jumlah tenaga kerja diterima berpengaruh positif terhadap pendapatan petani secara signifikan.

H4. Biaya transpor berpengaruh positif terhadap pendapatan petani secara signifikan.

H5. Biaya input berpengaruh positif terhadap pendapatan petani secara signifikan.

H6. Pola kemitraan berpengaruh positif terhadap pendapatan petani secara signifikan.

H7. Pengetahuan status HD berpengaruh positif terhadap pendapatan petani secara signifikan. 
H8. Partisipasi perencanaan berpengaruh positif terhadap pendapatan petani secara signifikan.

H9. Partisipasi pelaksanaan berpengaruh positif terhadap pendapatan petani secara signifikan.

H10. Partisipasi monev berpengaruh positif terhadap pendapatan petani secara signifikan.

\section{Metodologi Penelitian}

\section{Lokasi Penelitian}

Identifikasi dampak ekonomi, sosial dan lingkungan dari perhutanan sosial dilakukan di lokasi Kabupaten Berau. Lokasi penelitian ini dipilih karena sudah ditetapkan sebagai Provinsi percontohan perhutanan sosial di Indonesia, sehingga sampel penelitian diambil pada HD Merabu selama Bulan Maret-Mei 2018.

Lokasi survei dilakukan diKampung Merabu, Kecamatan Kelay, Kabupaten Berau, Provinsi Kalimantan Timur. Lokasi penelitian di wilayah tersebut memiliki areal HD seluas +8.250 ha.

\section{Unit Analisis dan Informan}

Unit analisis dalam penelitian ini adalah anggota kelompok tani. Kelompok tani yang diwawancarai terdiri dari kelompok Peledao (karet) dan Padi Ladang. Unit analisis yang dikaji untuk Provinsi Kalimantan Timur adalah anggota kelompok HD Kampung Merabu.

Teknik penentuan informan dilakukan dengan metode cluster sampling dan purposive sampling. Cluster sampling disebut juga area sampling. Cluster sampling digunakan ketika elemen dari populasi secara geografis tersebar luas sehingga sulit disusun sampling frame. Keuntungan penggunaan teknik ini adalah menjadikan proses sampling lebih murah dan cepat dibandingkan menggunakan teknik random sampling (Cooper \& Schindler dalam Kuncoro, 2013). Dalam konteks ini, hutan HD yang dipilih sebagai kluster adalah Hutan Desa di Kampung Merabu.

Teknik penentuan responden menggunakan purposive sampling (sampel bertujuan). Teknik ini merupakan pengambilan sampel secara sengaja sesuai dengan persyaratan sampel yang disyaratkan misalnya terkait sifat, karakteristik, kriteria, dan sebagainya. Responden dalam penelitian adalah anggota kelompok tani HD. Jumlah responden untuk lokasi HD adalah 53 orang. Untuk mempertajam analisis, peneliti juga melakukan wawancara ke informan lain yaitu pengurus kelompok tani, kelompok sadar wisata (pokdarwis), Gabungan Kelompok Tani (gapoktan), anggota kelompok tani, unit usaha dari kelompok HD serta dari pemerintah (bupati, dinas kehutanan, camat, pemerintah desa/pekon, dukuh) dan LSM. 
Juliansyah Roy, Mudrajad Kuncoro, Dio Caisar Darma

\section{Teknik Pengumpulan Data}

a. Observasi

Langkah pertama yang dilakukan dalam penelitian ini adalah observasi. Bentuk observasi yang dilakukan dalam penelitian ini adalah melihat langsung di lokasi penelitian yakni aktivitas-aktivitas yang dilakukan oleh para petani, peternak, pokdarwis, gapoktan dan pelaku ekonomi lainnya di HD. Proses observasi awal dilakukan pada saat pra-survei, kemudian pada saat pelaksanaan penelitian berlangsung.

b. Dokumentasi

Tahap ini merupakan pengumpulan dengan memanfaatkan data sekunder untuk mendukung hasil riset seperti profil Kampung Merabu, data BPS masing-masing lokasi, (Kecamatan Kelay dalam Angka, Kabupaten Berau Dalam Angka, Statistik Kesejahteraan Sosial), Kesatuan Pengelolaan Hutan Produksi (KPHP) Berau Barat, data tutupan lahan dan sebagainya.

c. Wawancara (Indepth Interview)

Wawancara mendalam dalam penelitian dilakukan kepada masing masing 53 petani di masing-masing lokasi HD. Agar data lebih komprehensif maka wawancara juga ditujukan kepada bupati, sekda, kepala desa, camat, dukuh, dan Organisasi Perangkat Daerah (OPD) terkait yakni Dinas Kehutanan, Dinas Lingkungan Hidup, Dinas Pariwisata, Dinas Pertanian, dan sebagainya.

d. Focused Group Discussion (FGD)

Metode FGD dilakukan dengan mengundang stakeholders terkait (kelompok tani, pemerintah desa, pemerintah kecamatan, dan Organisasi Perangkat Daerah terkait). FGD secara khusus juga dilakukan kepada anggota kelompok HD di masing-masing lokasi penelitian. FGD ini dilakukan untuk memperoleh umpan balik dari hasil survei yang dilakukan pada responden.

\section{Teknik Analisis Data}

a. Validasi Data

Validasi data dilakukan dengan pemilahan data dari hasil catatan di lapangan dan menentukan data mana yang dapat digunakan dan valid. Data yang diperlukan akan dikembangkan dan dipertajam sesuai dengan fokus penelitian.

b. Penarikan Kesimpulan dan Verifikasi

Tahap selanjutnya dari penelitian ini adalah penarikan kesimpulan. Upaya menarik kesimpulan ini dilakukan dengan mendasarkan pada bukti dan data yang valid sehingga kesimpulan yang diperoleh adalah kesimpulan yang benar-benar kredibel.

\section{Model Analisis}

a. Analisis Cross Tabulation (Tabulasi Silang)

Analisis crosstabs yang digunakan adalah analisis statistic yaitu Chi Kuadrat 
(Chi-Square). Metode analisis ini digunakan untuk menguji korelasi antara variabel dalam tabel kontigensi sehingga diketahui apakah proporsi dari dua perubahan terjadi karena kebutuhan atau karena adanya asosiasi. Tabulasi silang digunakan untuk mentabulasikan beberapa variabel yang berbeda ke dalam suatu matriks. Variabel yang ditabulasi silang adalah:

1. Jumlah tenaga kerja sebelum dan sesudah menerima SK HD;

2. Rasio biaya dan jumlah tenaga kerja sesudah menerima SK HD.

b. Analisis Regresi Linear Berganda

Model yang digunakan dalam penelitian ini adalah regresi linear berganda (multiple regression). Regresi linear berganda, menurut Gujarati (2009) adalah sebagai kajian terhadap ketergantungan satu variabel, yaitu variabel dependen terhadap satu atau lebih variabel independen lainnya dengan tujuan untuk membuat estimasi dan atau memprediksi rata-rata populasi.

Penelitian ini menggunakan analisis regresi linier berganda dengan beberapa uji statistik, uji koefisien determinasi dan uji asumsi Klasik. Pengolahan data sekunder dilakukan menggunakan aplikasi program SPSS Version 23.0 berdasarkan metode kuadrat terkecil disebut juga dengan metode Ordinary Least Square (OLS). Hal ini dimungkinkan untuk menganalisis sejauh mana pengaruh lama SK diterima, luas lahan, jumlah tenaga kerja, biaya transpor, biaya input, pola kemitraan, pengetahuan status HD, partisipasi perencanaan, dan partisipasi pelaksanaan, serta partisipasi monitoring dan evaluasi terhadap pendapatan petani Kampung Merabu selama tahun diberlakukannya status HD pada tahun 2014.

Adapun urutan perhitungan yang akan dilakukan adalah dengan membuat model ekonometrika yang disusun dalam bentuk model empirik yaitu (Gujarati, 2003):

$$
\mathrm{Y}=\mathrm{a}+\mathrm{X} 1, \mathrm{X} 2+\ldots .+\mathrm{e}
$$

Dari persamaan 1, kemudian dispesifikasi ke dalam model linear sebagai berikut :

$$
\begin{aligned}
\mathrm{Y}= & \alpha+\mathrm{X} 1 \beta 1+\mathrm{X} 2 \beta 2+\mathrm{X} 3 \beta 3+\mathrm{X} 4 \beta 4+\mathrm{X} 5 \beta 5+\mathrm{X} 6 \beta 6+\mathrm{X} 7 \beta 7 \\
& +\mathrm{X} 8 \beta 8+\mathrm{X} 9 \beta 9+\mathrm{X} 10 \beta 10+\varepsilon
\end{aligned}
$$

dimana:

Yadalah pendapatan petani

aadalah konstanta

X1 adalah lama SK diterima

X2 adalah luas lahan

X3 adalah jumlah tenaga kerja

X4 adalah biaya transport 


$\begin{array}{ll}\text { X5 } & \text { adalah biaya input } \\ \text { X6 } & \text { adalah pola kemitraan } \\ \text { X7 } & \text { adalah pengetahuan status HD } \\ \text { X8 } & \text { adalah partisipasi perencanaan } \\ \text { X9 } & \text { adalah partisipasi pelaksanaan } \\ \text { X10 } & \text { adalah partisipasi monev } \\ \beta 1 \beta 2 \ldots & \text { adalah koefisien regresi } \\ \varepsilon \text { adalah erorr term (faktor pengganggu) }\end{array}$

\section{Hasil Penelitian}

\section{Deskripsi Cross Tabulation}

Penyerapan tenaga kerja merupakan satu diantara tingkat keberhasilan pembangunan ekonomi suatu wilayah. Tenaga kerja yang terserap sebagai faktor produksi dalam proses pengolahan dan distribusi suatu perusahaan, lembaga tertentu, pemerintahan atau lainnya yang menghasilkan barang maupun jasa periode tertentu. Penyerapan tenaga kerja secara operasional dalam kajian ini adalah angkatan kerja (petani atau peternak) yang bergerak dalam subsektor pertanian, kehutanan, perikanan maupun perkebunan, baik itu mulai dari budidaya/pengembangan, penanaman benih, merawat hingga mengolah atau turut membantu pasca panen semenjak terbit atau sebelum adanya SK HD di Kampung Merabu.

Secara keseluruhan, dapat ditarik kesimpulan bahwa penggunaan tenaga kerja bagi kelompok petani/peternak yang memanfaatkan lahan di Kampung Merabu, baik sebelum dan sesudah terbitnya SK HD, berkisar 5 orang. Para petani tersebut melibatkan seluruh anggota keluarga (suami, istri, anak, serta keluarga lainnya maupun kerabat sesama kelompok tani) untuk mengolah lahan menjadi tanaman pertanian, tanaman sampingan dan budi daya ternak sampai pengolahan pasca panen. Sistem atau tradisi petani ini masih tergolong tradisional, dimana kebanyakan responden menjawab jika tenaga kerja yang ada bersifat sukarela atau tidak dibayar, karena sifat gotong royong diantara mereka masih berjalan hingga kini tanpa dibayar atau secara sukarela. Begitu pula dalam proses perawatan benih tanaman pertanian/perkebunan serta pengembangan ternak juga masih melibatkan orang-orang terdekat sekitar dengan pola rolling dengan jarak waktu yang berdekatan menggunakan alat-alat pertanian yang belum canggih, bahkan masih tradisional (cangkul, chainshaw, dan lainnya). Umumnya, para petani di Kampung Merabu memanfaatkan uang iuran Gabungan Kelompok Tani (Gapoktan) dari berbagai jenis tanaman maupun ada juga yang masih swasembada untuk membiayai konsumsi panen berupa: makanan, minuman, rokok, dan kebutuhan lapangan lainnya. 
Kajian Dampak Ekonomi Hutan Desa...

Tabel 1. Perbandingan Tabulasi Silang (Jumlah Tenaga Kerja

Sebelum dan Sesudah Menerima SK HD)

\begin{tabular}{|c|c|c|c|c|c|c|c|c|c|c|c|c|c|c|}
\hline \multicolumn{14}{|c|}{ Jumlan $/ K$ sesurahan } & \multirow[b]{2}{*}{ Total } \\
\hline & & & 1 & 2 & 3 & 4 & \begin{tabular}{l|l}
5 & \\
\end{tabular} & \begin{tabular}{l|l}
6 & \\
6
\end{tabular} & 7 & 9 & 10 & 13 & 20 & \\
\hline \multirow[t]{43}{*}{ Persen biaya TK 0} & & $\begin{array}{l}\text { Count } \\
\% \text { of Total }\end{array}$ & $\begin{array}{r}6 \\
113 \%\end{array}$ & $\begin{array}{r}8 \\
15,1 \%\end{array}$ & $132 \%$ & $\begin{array}{r}0 \\
0 \%\end{array}$ & $\begin{array}{r}0 \\
0 \%\end{array}$ & $\begin{array}{r}1 \\
1,9 \%\end{array}$ & $\begin{array}{r}2 \\
38 \%\end{array}$ & $\begin{array}{r}0 \\
0 \%\end{array}$ & $\begin{array}{r}3 \\
57 \%\end{array}$ & $\begin{array}{r}0 \\
0 \%\end{array}$ & $\begin{array}{r}1 \\
1.9 \%\end{array}$ & $\begin{array}{r}28 \\
528 \%\end{array}$ \\
\hline & $\overline{0.02 C}$ & ount & 0 & 1 & 0 & 0 & 0 & 0 & 0 & 0 & 0 & 0 & 0 & \\
\hline & & $\%$ of Total &, $0 \%$ & $1,9 \%$ &, $0 \%$ & $0 \%$ &, $0 \%$ &, $0 \%$ &, $0 \%$ &, $0 \%$ &, $0 \%$ &, $0 \%$ &, $0 \%$ & $1,9 \%$ \\
\hline & $\overline{0.07 \mathrm{C}}$ & ount & 0 & 1 & 0 & 0 & 0 & 0 & 0 & 0 & 0 & 0 & 0 & 1 \\
\hline & & $\%$ of Total & , $0 \%$ & $1,9 \%$ & ,0\% & ,0\% & , $0 \%$ & , $0 \%$ &, $0 \%$ &, $0 \%$ & ,0\% &, $0 \%$ &, $0 \%$ & $1,9 \%$ \\
\hline & 0.1 & Count & 0 & 0 & 0 & 1 & 0 & 0 & 0 & 1 & 0 & 0 & 0 & 2 \\
\hline & & $\%$ of Total &, $0 \%$ & ,0\% & ,0\% & $1,9 \%$ & , $0 \%$ &, $0 \%$ &, $0 \%$ & $1,9 \%$ & ,0\% &, $0 \%$ &, $0 \%$ & $3,8 \%$ \\
\hline & $\overline{0.18 \mathrm{C}}$ & ount & 0 & 0 & 1 & 0 & 0 & 0 & 1 & 0 & 0 & 0 & 0 & 2 \\
\hline & & $\%$ of Total &, $0 \%$ & ,0\% & $1,9 \%$ &, $0 \%$ & ,0\% &, $0 \%$ & $1,9 \%$ &, $0 \%$ &, $0 \%$ &, $0 \%$ &, $0 \%$ & $3,8 \%$ \\
\hline & 0.2 & Count & 0 & 0 & 0 & 0 & 1 & 0 & 0 & 0 & 0 & 0 & 0 & 1 \\
\hline & & $\%$ of Total &, $0 \%$ & ,0\% & ,0\% &, $0 \%$ & $1,9 \%$ &, $0 \%$ &, $0 \%$ & ,0\% & ,0\% &, $0 \%$ &, $0 \%$ & $1,9 \%$ \\
\hline & $\overline{0.26 \mathrm{C}}$ & ount & 0 & 0 & 0 & 0 & 0 & 0 & 0 & 0 & 1 & 0 & 0 & 1 \\
\hline & & $\%$ of Total & $.0 \%$ & $0 \%$ & ,0\% &, $0 \%$ & ,0\% & , $0 \%$ &, $0 \%$ &, $0 \%$ & $1,9 \%$ & ,0\% &, $0 \%$ & $1,9 \%$ \\
\hline & 0.3 & Count & 0 & 1 & 0 & 0 & 0 & 0 & 1 & 0 & 0 & 1 & 0 & 3 \\
\hline & & $\%$ of Total & $.0 \%$ & $1,9 \%$ & ,0\% &, $0 \%$ & ,0\% & ,0\% & $1,9 \%$ &, $0 \%$ & ,0\% & $1,9 \%$ &, $0 \%$ & $5,7 \%$ \\
\hline & $\overline{0.38 \mathrm{C}}$ & ount & 0 & 0 & 0 & 0 & 0 & 0 & 1 & 0 & 0 & 0 & 0 & 1 \\
\hline & & $\%$ of Total &, $0 \%$ & ,0\% & ,0\% &, $0 \%$ & , $0 \%$ & , $0 \%$ & $1,9 \%$ &, $0 \%$ & ,0\% &, $0 \%$ &, $0 \%$ & $1,9 \%$ \\
\hline & $\overline{0.44 \mathrm{C}}$ & ount & 0 & 0 & 0 & 0 & 0 & 0 & 1 & 0 & 0 & 0 & 0 & 1 \\
\hline & & $\%$ of Total &, $0 \%$ & ,0\% & , $0 \%$ & ,0\% & , $0 \%$ & ,0\% & $1,9 \%$ & ,0\% & , $0 \%$ &, $0 \%$ &, $0 \%$ & $1,9 \%$ \\
\hline & $\overline{0.49 \mathrm{C}}$ & ount & 0 & 0 & 0 & 0 & 1 & 0 & 0 & 0 & 0 & 0 & 0 & 1 \\
\hline & & $\%$ of Total &, $0 \%$ & ,0\% & ,0\% &, $0 \%$ & $1,9 \%$ &, $0 \%$ &, $0 \%$ & ,0\% & ,0\% &, $0 \%$ &, $0 \%$ & $1,9 \%$ \\
\hline & $\overline{0.56 \mathrm{C}}$ & ount & 0 & 0 & 0 & 0 & 1 & 0 & 0 & 0 & 0 & 0 & 0 & 1 \\
\hline & & $\%$ of Total &, $0 \%$ &, $0 \%$ &, $0 \%$ & ,0\% & $1,9 \%$ & , $0 \%$ &, $0 \%$ &, $0 \%$ &, $0 \%$ &, $0 \%$ &, $0 \%$ & $1,9 \%$ \\
\hline & $0.59 \mathrm{C}$ & ount & 0 & 1 & 0 & 0 & 0 & 0 & 0 & 0 & 0 & 0 & 0 & 1 \\
\hline & & $\%$ of Total &, $0 \%$ & $1,9 \%$ & , $0 \%$ &, $0 \%$ & , $0 \%$ & , $0 \%$ & ,0\% &, $0 \%$ & , $0 \%$ &, $0 \%$ &, $0 \%$ & $1,9 \%$ \\
\hline & 0.6 & Count & 0 & 0 & 0 & 1 & 0 & 0 & 0 & 0 & 0 & 0 & 0 & 1 \\
\hline & & $\%$ of Total &, $0 \%$ &, $0 \%$ &, $0 \%$ & $1,9 \%$ &, $0 \%$ &, $0 \%$ &, $0 \%$ &, $0 \%$ &, $0 \%$ &, $0 \%$ &, $0 \%$ & $1,9 \%$ \\
\hline & $\overline{0.63 \mathrm{C}}$ & ount & 0 & 0 & 1 & 0 & 0 & 0 & 0 & 0 & 0 & 0 & 0 & 1 \\
\hline & & $\%$ of Total &, $0 \%$ & ,0\% & $1,9 \%$ &, $0 \%$ & , $0 \%$ & , $0 \%$ &, $0 \%$ &, $0 \%$ &, $0 \%$ &, $0 \%$ &, $0 \%$ & $1,9 \%$ \\
\hline & $\overline{0.68 \mathrm{C}}$ & ount & 0 & 0 & 0 & 0 & 0 & 1 & 0 & 0 & 0 & 0 & 0 & 1 \\
\hline & & $\%$ of Total & $.0 \%$ &, $0 \%$ &, $0 \%$ &, $0 \%$ & ,0\% & $1,9 \%$ &, $0 \%$ &, $0 \%$ &, $0 \%$ &, $0 \%$ &, $0 \%$ & $1,9 \%$ \\
\hline & 0.7 & Count & 0 & 0 & 1 & 0 & 0 & 0 & 0 & 0 & 0 & 0 & 0 & \\
\hline & & $\%$ of Total & , $0 \%$ &, $0 \%$ & $1,9 \%$ &, $0 \%$ & , $0 \%$ & , $0 \%$ &, $0 \%$ & ,0\% & , 0\% &, $0 \%$ &, $0 \%$ & $1,9 \%$ \\
\hline & $\overline{0.73 C}$ & ount & 0 & 0 & 0 & 0 & 0 & 0 & 0 & 1 & 0 & 0 & 0 & \\
\hline & & $\%$ of Total &, $0 \%$ & , $0 \%$ & , $0 \%$ &, $0 \%$ & , $0 \%$ & , $0 \%$ &, $0 \%$ & $1,9 \%$ & , $0 \%$ &, $0 \%$ &, $0 \%$ & $1,9 \%$ \\
\hline & $\overline{0.76 \mathrm{C}}$ & ount & 0 & 0 & 0 & 0 & 0 & 0 & 0 & 1 & 0 & 0 & 0 & \\
\hline & & $\%$ of Total &, $0 \%$ & $0 \%$ & ,0\% &, $0 \%$ & , $0 \%$ & , $\% \%$ &, $0 \%$ & $1,9 \%$ & , $0 \%$ &, $0 \%$ &, $0 \%$ & $1,9 \%$ \\
\hline & $0.87 \mathrm{C}$ & ount & 0 & 1 & 0 & 0 & 0 & 0 & 0 & 0 & 0 & 0 & 0 & \\
\hline & & $\%$ of Total &, $0 \%$ & $1,9 \%$ & ,0\% &, $0 \%$ & , $0 \%$ & , $0 \%$ &, $0 \%$ &, $0 \%$ &, $0 \%$ &, $0 \%$ &, $0 \%$ & $1,9 \%$ \\
\hline & 0.9 & Count & 0 & 0 & 0 & 0 & & 0 & 0 & 0 & 0 & 0 & 0 & \\
\hline & & $\%$ of Total &, $0 \%$ &, $0 \%$ &, $0 \%$ &, $0 \%$ & $1,9 \%$ &, $0 \%$ & , $0 \%$ & ,0\% & , $0 \%$ &, $0 \%$ &, $0 \%$ & $1,9 \%$ \\
\hline & $\overline{0.95 \mathrm{C}}$ & ount & 0 & 0 & 1 & 0 & 0 & 0 & 0 & 0 & 0 & 0 & 0 & 1 \\
\hline & & $\%$ of Total &, $0 \%$ &, $0 \%$ & $1,9 \%$ &, $0 \%$ & ,0\% & ,0\% &, $0 \%$ &, $0 \%$ &, $0 \%$ & $.0 \%$ &, $0 \%$ & $1,9 \%$ \\
\hline \begin{tabular}{|l|} 
Total \\
\end{tabular} & & Count & 6 & 13 & 11 & 2 & 4 & 2 & 6 & 3 & 4 & 1 & 1 & 53 \\
\hline & & $\%$ of Total & $11,3 \%$ & $24,5 \%$ & $20,8 \%$ & $3,8 \%$ & $7,5 \%$ & $3,8 \%$ & $11,3 \%$ & $5,7 \%$ & $7,5 \%$ & $1,9 \%$ & $1,9 \%$ & $100,0 \%$ \\
\hline
\end{tabular}

Keterangan:

1) Nilai Pearson Chi-Square: 239,512 , yang signifikan pada derajat $95 \%$.

2) 121 cells $(100 \%)$ have expected count less than 5 . The minimum

Expected count is 0,2 .

Sumber: Diolah dari data primer (2018)

Dampak tenaga kerja terlihat melalui hasil crosstabulation pada Tabel 1 yang menggambarkan kondisi jumlah tenaga kerja sebelum dan sesudah menerima SK HD.Baik sebelum maupun sesudah menerima SK HD, petani bidang tanaman utama dan sampingan yang bekerja sendiri adalah konstan (9,09\%). Usaha tani sebelum adanya HD menyerap 1 orang atau 32,08\%, kini meningkatmenjadi 2 hingga 3 orang $(9,4 \%)$. Sedang petani yang menyerap 2-3 orang sebelum menerima status HD sebanyak 47,2\% mengalami peningkatan menjadi 3 hingga 10 orang. Pada petani yang menggunakan tenaga kerjadi atas 5 orang sebelum SK HD(5,7\%) meningkat menjadi 6-8 orang setelah menerma SK HD. Dari tabulasi silang diatas, terlihat bahwa semakin banyak petani menggunakan tenaga kerja di saat sudah menerima SK HD. Ada kecenderungan akan semakin bertambah untuk memberdayakan angkatan 
Juliansyah Roy, Mudrajad Kuncoro, Dio Caisar Darma

kerja. Demikian pula pada peningkatan skala usaha tani di Kampung Merabu (Kabupaten Berau), diperkuat dengan nilai Chi-Square yaitu 239,512, yang signifikan pada tingkat (derajat) kepercayaan 99\%. Dengan kata lain, terjadi peningkatan penerapan tenaga kerja yang signifikan antara sebelum dan setelah menerima SK HD. Kendati demikian, kecenderungan umumnya meningkatnya skala usaha dari usaha mikro, yang menyerap 1-4 pekerja, menjadi usaha kecil yang menyerapa tenaga kerja 5-20 orang.

Dari aktivitas ekonomi wisata di Kampung Merabu, proses monitoring kelompok semacam sadar wisata yang dibentuk dalam lembaga Kerima Puri (beranggotakan 12 orang saat ini), kenyataan dilapangan ternyata hanya berkisar 3-4 orang saja yang ikut terlibat. Adanya home stay atau penginapan khusus bagi turis berjumlah 2 tempat, catering bersifat rolling (dikelola oleh golongan masyarakat tertentu) dan sama halnya dengan ketinting di Desa ini sekitar 5-7 buah, pemiliknya yakni kepala adat, kepala Desa, atau orang-orang tertentu saja.

Kenyataan seperti diatas, tentu tidak terlepas dari pendapat dan pernyataan masyarakat saat pelaksanaan wawancara melalui teknik kuesioner. Pada umumnya, responden masih mengeluhkan akan hal tersebut dan masih kurang diberdayakan secara utuh. Padahal, sebagian masyarakat Kampung Merabu, khususnya anggota rumah tangga (para istri) ingin betul ikut andil dalam kegiatan seperti pengembangan wisata. Jasa tour guide pun belum ada di Kampung Merabu yang memanfaatkan orang lokal. Akibatnya, kebanyakan turis dari berbagai negara sampai saat ini jika berkunjung masih menggunakan jasa dari wilayah/kota lain, seperti Jakarta, Berau, Samarinda dan sekitarnya. Dengan begitu, belum ada serapan tenaga kerja yang berarti pada sektor ini, pembuktiaan nyata hanya beberapa oknum saja dapat menikmati hasil kekayaan alam berupa wisata, yang merupakan peninggalan dari nenek moyang leluhur mereka sendiri.

Rasio biaya tenaga kerja merupakan perbandingan biaya tenaga kerja dengan total biaya. Rasio biaya digunakan untuk mengetahui seberapa besar proporsi biaya tenaga kerja dibandingkan total biaya. Berdasarkan perhitungan, rerata rasio biaya tenaga kerja adalah $30 \%$.

Tabel 2 memperlihatkan hasil tabulasi silang antara rasio biaya tenaga kerja dan jumlah tenaga kerja. Responden dengan interval rasio biaya tenaga kerja pada Kelas 1 (0-10\%) merupakan responden dengan jumlah terbanyak $(60,5 \%)$. Posisi kedua, disusul oleh Kelas 3 (20,1-30\%) yakni 7,6\%. Berikutnya responden pada Kelas 4 (30,1-40\%) dan Kelas 10 (90,1-100\%) merupakan rasio interval terendah dibanding lainnya yang masing-masing sebanyak $1,9 \%$ dari total responden. 
Kajian Dampak Ekonomi Hutan Desa...

Tabel 2. Cross tabulation antara Rasio Biaya Tenaga Kerja

dan Jumlah Tenaga Kerja Sesudah Menerima SK HD

\begin{tabular}{|c|c|c|c|c|c|c|c|c|c|c|c|c|c|}
\hline \multirow[t]{2}{*}{ Kelas } & \multirow{2}{*}{$\begin{array}{c}\text { Interval } \\
\text { Biaya } \\
\text { TK }\end{array}$} & \multicolumn{11}{|c|}{ Jumlah TK (\%) } & \multirow[t]{2}{*}{ Total } \\
\hline & & 1 & 2 & 3 & 4 & 5 & 6 & 7 & 9 & 10 & 13 & 20 & \\
\hline 1 & $\begin{array}{c}0,000- \\
0,1\end{array}$ & 11,3 & 18,9 & 13,2 & 1,9 & 0,0 & 1,9 & 3,8 & 1,9 & 5,7 & 0,0 & 1,9 & 60,5 \\
\hline 2 & $\begin{array}{c}0,101- \\
0,2\end{array}$ & 0,0 & 0,0 & 1,9 & 0,0 & 1,9 & 0,0 & 1,9 & 0,0 & 0,0 & 0,0 & 0,0 & 5,7 \\
\hline 3 & $\begin{array}{c}0,201- \\
0,3\end{array}$ & 0,0 & 1,9 & 0,0 & 0,0 & 0,0 & 0,0 & 1,9 & 0,0 & 1,9 & 1,9 & 0,0 & 7,6 \\
\hline 4 & $\begin{array}{c}0,301- \\
0,4\end{array}$ & 0,0 & 0,0 & 0,0 & 0,0 & 0,0 & 0,0 & 1,9 & 0,0 & 0,0 & 0,0 & 0,0 & 1,9 \\
\hline 5 & $\begin{array}{c}0,401- \\
0,5\end{array}$ & 0,0 & 0,0 & 0,0 & 0,0 & 1,9 & 0,0 & 1,9 & 0,0 & 0,0 & 0,0 & 0,0 & 3,8 \\
\hline 6 & $\begin{array}{c}0,501- \\
0,6\end{array}$ & 0,0 & 1,9 & 0,0 & 1,9 & 1,9 & 0,0 & 0,0 & 0,0 & 0,0 & 0,0 & 0,0 & 5,7 \\
\hline 7 & $\begin{array}{c}0,601- \\
0,7\end{array}$ & 0,0 & 0,0 & 3,8 & 0,0 & 0,0 & 1,9 & 0,0 & 0,0 & 0,0 & 0,0 & 0,0 & 5,7 \\
\hline 8 & $\begin{array}{c}0,701- \\
0,8\end{array}$ & 0,0 & 0,0 & 0,0 & 0,0 & 0,0 & 0,0 & 0,0 & 3,8 & 0,0 & 0,0 & 0,0 & 3,8 \\
\hline 9 & $\begin{array}{c}0,801- \\
0,9\end{array}$ & 0,0 & 1,9 & 0,0 & 0,0 & 1,9 & 0,0 & 0,0 & 0,0 & 0,0 & 0,0 & 0,0 & 3,8 \\
\hline 10 & $\begin{array}{c}0,901- \\
1,0\end{array}$ & 0,0 & 0,0 & 1,9 & 0,0 & 0,0 & 0,0 & 0,0 & 0,0 & 0,0 & 0,0 & 0,0 & 1,9 \\
\hline Total & & 11,3 & 24,6 & 20,8 & 3,8 & 7,6 & 3,8 & 11,4 & 5,7 & 7,6 & 1,9 & 1,9 & 100,0 \\
\hline
\end{tabular}

Keterangan: (*) Rerata rasio biaya tenaga kerja adalah9,14\%

Sumber: Diolah dari data primer (2018)

Secara benang merah, banyaknya responden dengan rasio biaya pada Kelas 1 dan telah menggunakan 2 tenaga kerja (pemilik lahan) adalah 18,9\% dan Kelas 3 merupakan interval terbanyak kedua, dimana penggunaan tenaga kerja berjumlah 2, 7, 10 hingga 13 orang secara kumulatif adalah 7,6\%. Banyaknya petani di wilayah Kampung Merabu terlihat masih mampu menggarap atau mengolah lahan persilnya sendiri dan tidak mengandalkan orang lain, karena dianggap menghemat untuk meniadakan upah tenaga kerja. Adapun 2 orang tenaga kerja yang menggarap lahan, kebanyakan ialah para istri petani atau anak mereka yang membantu untuk berladang padi, beternak sapi/ayam/maupun itik atau menanam tanaman sampingan seperti: sahang, gambas, kacang-kacangan dan sebagainya. 
Adanya perbedaan pada jumlah tenaga kerja sebesar 10, 13 dan 20 orang, seperti yang perlu dicermati adalah termasuk usaha tani dalam skala besar (perkebunan karet, gaharu dan lain-lain) membutuhkan tenaga kerja lapangan yang sangat ekstra. Seharusnya, dengan keterlibatan angka tenaga kerja sebesar itu dapat meningkatkan pendapatan per kapita di Kampung Merabu serta berdampak terhadap sektor maupun subsektor yang lain. Fakta empiris membuktikan bahwa tidak seluruhnya hipotesis rantai/roda perekonomian saat tim dilapangan berlaku, namun justru berbanding terbalik. Hal ini dikarenakan pola pertanian, perkebunan dan sebagainya oleh para petani masih berbentuk tradisional, karena sebagian besar tanaman utama mereka berupa padi ladang yang masa panennya hanya 1-2 kali selama 1 tahun dan itupun walaupun tenaga kerja untuk menggarap lahan sampai mengolah atau proses penggarapannya tidak dibayar (berbasis sukarela/gotong royong).

\section{Faktor-faktor Penentu Pendapatan}

Pada bagian ini ini akan menganalisis serta mengidentifikasi faktorfaktor apa saja yang menentukan pendapatan kelompok HD di Kampung Merabu. Model statisktik tertuang menjadi variabel dependen (terikat) yakni total pendapatan petani yang yang dipengaruhi oleh beberapa variabel independen (bebas) yaitu: (1) Lama SK Diterima; (2) Luas Lahan; (3) Jumlah Tenaga Kerja; (4) Biaya Transpor; (5) Biaya Input; (6) Pola Kemitraan; (7) Pengetahuan Status HD; (8) Partisipasi Perencanaan; (9) Partisipasi Pelaksanaan; serta (10) Partisipasi Monev.

Adapun penyajian data melalui bantuan program komputer SPSS Version 23.0 for Windows. Tahapan-tahapan penyajian statsitik deksriptif terdiri dari: (1) Uji Koefisien Korelasi dan Determinasi; (2) Uji F-Statistik; dan (3) Uji-t Statistik; dan (4) Uji Penyimpangan Asumsi Klasik. Berikut ini data hasil perhitungan dari lampiran (output SPSS) dengan penjabaran analisis berikut ini dengan tingkat probability 0,05 (5\%).

Pertama, Uji Koefisien Korelasi (R) digunakan untuk menjawab seberapa erat, atau seberapa kuat hubungan linier antara variabel bebas $(X)$ dan variabel terikat (Y). Koefisien kolerasi yang digunakan dalam penelitian adalah Pearson Correlation Coefficient. Sedangkan, Uji Koefisien Determinasi (R2) digunakan untuk mengetahui besarnya pengaruh antara variabel tidak bebas dengan variabel bebas. Semakin besar nilai R2, maka semakin tepat model regresi yang dipakai sebagai alat analisis, karena total variasi dapat menjelaskan variabel tidak bebas.

Untuk mengetahui pengaruh 10 variabel bebas terhadap Pendapatan petani (Y) Kampung Merabu dapat dilihat dari nilai R dan Determinasi R2. Dari hasil analisis data, diketahui bahwa nilai $\mathrm{R}$ sebesar 0,666 artinya secara 
statistik menggambarkan kuatnya hubungan dari kesepuluh variabel bebas terhadap variabel terikat. Hal ini menunjukkan terdapat hubungan dengan tingkatan yang kuat antara variabel bebas dan terikat yakni sebesar 66,6\%. Kemudian, agar dapat mengetahui sumbangan persentase antara variabelvariabel bebas terhadap variabel terikat, dapat dilihat dari nilai Koefisien Determinasi adalah:

\begin{tabular}{lccc}
\multicolumn{5}{c}{ Tabel 3. Hasil Koefisien Korelasi dan Determinasi } \\
\hline Model & R Square & $\begin{array}{l}\text { Adjusted R } \\
\text { Square }\end{array}$ & $\begin{array}{l}\text { Std. Error } \\
\text { of the } \\
\text { Estimate }\end{array}$ \\
\hline $666 \mathrm{a}$ & 444 &, 328 & $2,482 \mathrm{E7}$ \\
\hline \multicolumn{4}{c}{$\begin{array}{l}\text { a. Predictors: (Constant), X10, X9, X8, X7, X6, X5, X4, X3, X2, X1 } \\
\text { b. Dependent Variable: Y }\end{array}$} \\
Sumber: Output SPSS (2018)
\end{tabular}

Sumber: Output SPSS (2018)

Berdasarkan Tabel 3, diperoleh nilai besarnya R2 sebesar 0,444. Angka tersebut menunjukkan bahwa model dapat menjelaskan hubungan yang sedang antara kesemua variabel bebas terhadap pendapatan petani Kampung Merabu yakni 44,4\%. Sisanya sebesar 0,556 atau 55,6\% dijelaskan oleh faktor lain yang berada diluar model penelitian ini.

Kedua, Uji F-statistik dilakukan untuk melihat seberapa besar pengaruh variabel bebas secara bersama-sama terhadap variabel terikat. Pengujian ini dilakukan untuk membandingkan nilai F-hitung dengan F-tabel. Jika F-hitung $>$ F-tabel, maka Ho ditolak artinya variabel bebas secara bersama-sama mempengaruhi variabel terikat. Dan jika F-hitung < F-tabel, maka Ho diterima artinya variabel bebas secara bersama-sama tidak mempengaruhi variabel terikat. Agar dapat mengetahui kelayakan model variabel penelitian yang digunakan, maka digunakan Uji F. Pengujian ini digunakan untuk mengetahui adanya pengaruh secara simultan atau bersamaan adalah berikut:

Tabel 4. Hasil F-Statistik

\begin{tabular}{llll}
\hline Model & $\begin{array}{l}\text { Sum of } \\
\text { Squares }\end{array}$ & $\begin{array}{l}\text { Mean } \\
\text { Square }\end{array}$ & \\
\hline Regression & $2,116 \mathrm{E} 16$ & ,351E15 & ,816 \\
Residual & $2,649 \mathrm{E} 16$ & $26,161 \mathrm{E} 14$ & \\
Total & $4,765 \mathrm{E} 16$ & & \\
\hline
\end{tabular}

a. Dependent Variable: Y1

b. Predictors: (Constant), X10, X9, X8, X7, X6, X5, X4, X3, X2, X1

Sumber : Output SPSS (2018) 
Juliansyah Roy, Mudrajad Kuncoro, Dio Caisar Darma

Tabel 4 menunjukkan bahwa pengujian dengan menggunakan uji Fstatistik pada model penelitian, diketahui nilai F-hitung lebih kecil dari F-tabel $(3,816>2,06)$ pada derajat probabilitas F-statistik lebih kecil dari taraf nyata yang digunakan $(0,001<0,05)$ dengan tingkat kepercayaan $5 \%(\alpha=5 \%)$. Sehingga, dapat dikatakan bahwa variabel bebas yang digunakan dalam model ini secara bersama-sama berpengaruh signifikan terhadap Pendapatan Petani (Y) Kampung Merabu. Maka, hipotesis yang diajukan dapat diterima atau terbukti benar.

Tabel 5. Hasil t-Statitistik

\begin{tabular}{|c|c|c|c|c|c|}
\hline \multirow[b]{2}{*}{ Model } & \multicolumn{2}{|c|}{ Unstandardized Coefficients } & \multirow{2}{*}{$\begin{array}{l}\text { Standardized } \\
\text { Coefficients } \\
\text { Beta }\end{array}$} & & \multirow[b]{2}{*}{ Sig. } \\
\hline & $\mathrm{B}$ & Std. Error & & & \\
\hline (Constant) & $-51009693,984$ & 19390845,369 & & $-2,631$ & ,012 \\
\hline $\mathrm{X} 1$ & 11499087,800 & 4344132,526 & ,311 & 2,647 & 011 \\
\hline $\mathrm{X} 2$ & 1116745,270 & 1212221,139 & 108 & ,921 & ,362 \\
\hline X3 & 3204470,567 & 769247,408 & ,506 & 4,166 & ,000 \\
\hline $\mathrm{X} 4$ & 23735159,024 & 20198597,581 & 158 & 1,175 & ,246 \\
\hline $\mathrm{X} 5$ & 5567970,525 & 12358799,255 & 058 & ,451 & 655 \\
\hline $\mathrm{X} 6$ & $-648861,046$ & 1068593,137 &,- 072 &,- 607 &, 547 \\
\hline $\mathrm{X} 7$ & 2328721,246 & 11330184,262 & 025 & 206 & ,838 \\
\hline X8 & $-12295987,619$ & 10843893,487 &,- 325 & $-1,134$ & ,263 \\
\hline X9 & 1533690,945 & 1420840,038 &, 457 & 1,623 & ,112 \\
\hline $\mathrm{X} 10$ & 18116451,289 & 11724293,276 & 447 & 1,545 & 130 \\
\hline
\end{tabular}

Ketiga, Uji t-statistik merupakan suatu pengujian yang bertujuan untuk mengetahui apakah masing-masing koefisien regresi signifikan atau tidak terhadap variabel bebas dengan menganggap variabel terikat lainnya konstan. Pengujian ini dilakukan untuk membandingkan nilai t-hitung dengan t-tabel. Jika t-hitung > t-tabel, maka Ho ditolak artinya variabel bebas secara bersamasama mempengaruhi variabel terikat. Dan jika t-hitung $<\mathrm{t}$-tabel, maka Ho diterima artinya variabel bebas secara bersama-sama tidak mempengaruhi variabel terikat.

Dalam variabel penelitian, pengujian ini digunakan untuk mengetahui adanya pengaruh Lama SK Diterima (X1); Luas Lahan (X2); Jumlah Tenaga Kerja (X3); Biaya Transpor (X4); Biaya Input (X5); Pola Kemitraan (X6); Pengetahuan Status HD (X7); Partisipasi Perencanaan (X8); Partisipasi Pelaksanaan (X9); serta Partisipasi Monev (X10) terhadap Pendapatan petani (Y) Kampung Merabu secara parsial atau individual (lihat Tabel 5).

Dapat disimpulkan bahwa pengujian statistik secara parsial, hanya variabel Lama SK Diterima (X1) dan Jumlah Tenaga Kerja (X3) saja yang berpengaruh positif signifikan terhadap Pendapatan Petani (Y) Kampung Merabu. Secara kuantitatif dan kualitatif, hal tersebut disebabkan oleh rerata durasi atau lama penerimaan SK HD yang diterima oleh Petani di Kampung 
Merabu berkisar 2 - 4 tahun dan ini dianggap sudah pada proses pengolahan lahan hingga masa panen dan distribusi hasil usaha tani/ternak. Ini juga dibuktikan dengan output SPSS yang menunjukkan nilai mean 2,42 serta besaran standar deviation mencapai 0,819 dan selama jangka penelitian, distribusi kurva dalam variabel ini tidak berfuktuatif (trend stabil). Sama halnya dengan variabel Jumlah Tenaga Kerja, mean hitung mencapai angka 5,32 dan standar deviation sebesar 4,783. Dukungan data bila mengacu subbab sebelumnya, penyerapan angka tenaga kerja dalam lingkup usaha pertanian, perkebunan atau perikanan di Kampung Merabu memang saat ini bertambah (setelah penerbitan status HD) menjadi 247 orang, dimana sebelum adanya SK adalah 212 orang. Kenaikan serapan tenaga kerja petani walaupun tidak besar (berkisar 16,50\%), namun telah dianggap suatu kemajuan mengingat jumlah dan sebaran penduduk di Kampung Merabu masih tergolong kecil.

Berdasarkan bantuan program computer SPSS Version 23.0 for Windows, pada Tabel 5 dapat dioperasionalkan persamaan struktur untuk kesemua variabel bebas terhadap Pendapatan Petani yakni :

$$
\begin{aligned}
Y= & 0,311 X 1+0,108 X 2+0,506 X 3+0,158 X 4+0,058 X 5-0,072 \\
& X 6+0,025 X 7-0,325 X 8+0,457 X 9+0,447 X 10+0,556 \varepsilon
\end{aligned}
$$

Persamaan model penelitian, diketahui bahwa terdapat 2 variabel yang bernilai negatif, adalah Pola Kemitraan (X6) dan Partisipasi Perencanaan (X8). Dengan nilai koefisien regresi $(\beta)$ dari Pola Kemitraan yakni -0,072, dapat diinterpretasikan jika setiap angka Pola Kemitraan bertambah 1\%, maka Pendapatan Petani turun yakni 7,2\%. Selanjutnya, nilai koefisien regresi $(\beta)$ Partisipasi Perencanaan (X8) yakni -0,325, dapat diinterpretasikan jika setiap Partisipasi Perencanaan bertambah 1\%, maka Pendapatan Petani turun sebesar 32,5\%. Disisi lain, 8 variabel bebas diantaranya mempunyai hubungan positif yang dapat mempengaruhi Pendapatan Petani Kampung Merabu.

Keempat, pengujian penyimpangan asumsi klasik penelitian dalam model penelitian ini untuk melihat besaran dari Uji Multikolinearitas. Multikolineritas adalah alat untuk mengetahui suatu kondisi apakah didalam model regresi tersebut terdapat korelasi variabel independen diantara satu sama lainnya. Suatu model regresi dikatakan terkena multikolineritas bila terjadi hubungan linear yang sempurna atau pasti diantara beberapa atau semua variabel bebas dari suatu model regresi. Akibatnya, akan kesulitan untuk dapat melihat pengaruh antar variabel penelitian. Model regresi yang baik seharusnya tidak terjadi korelasi diantara variabel bebas. Pengujian multikoliniearitas memberikan hasil seperti ditunjukkan Tabel 6. 
Juliansyah Roy, Mudrajad Kuncoro, Dio Caisar Darma

Tabel 6. Hasil Multikolinieritas

\begin{tabular}{cccl}
\hline \multirow{2}{*}{ Model } & \multicolumn{2}{l}{ Collinearity Statistics } & Interpretasi \\
& Tolerance & VIF & Tidak terjadi multikolinearitas \\
1 & 0,936 & 1,068 & Tidak terjadi multikolinearitas \\
3 & 0,940 & 1,064 & Tidak terjadi multikolinearitas \\
4 & 0,875 & 1,142 & Tidak terjadi multikolinearitas \\
5 & 0,719 & 1,391 & Tidak terjadimultikolinearitas \\
6 & 0,775 & 1,291 & Tidak terjadi multikolinearitas \\
7 & 0,924 & 1,083 & Tidak terjadi multikolinearitas \\
8 & 0,902 & 1,109 & Tidak terjadi multikolinearitas \\
9 & 0,158 & 6,338 & Tidak terjadi multikolinearitas \\
10 & 0,154 & 6,474 & Tidak terjadi multikolinearitas
\end{tabular}

a. Dependent Variable: Y

Sumber: Output SPSS (2018)

Dari output diketahui besaran VIF hitung $<$ VIF $=10$, tolerance variabel bebas pada model atau struktur penelitian yakni: Lama SK Diterima (X1); Luas Lahan (X2); Jumlah Tenaga Kerja (X3); Biaya Transpor (X4); Biaya Input (X5); Pola Kemitraan (X6); Pengetahuan Status HD (X7); Partisipasi Perencanaan (X8); Partisipasi Pelaksanaan (X9); serta Partisipasi Monev (X10) tidak terjadi atau tidak mengalami masalah multikolinearitas.

Selanjutnya, pengujian penyimpangan asumsi klasik penelitian dalam model untuk melihat besaran dari Uji Autokorelasi. Autokorelasi adalah korelasi (hubungan) yang terjadi antara anggota-anggota dari serangkaian pengamatan yang tersusun dalam rangkaian waktu (time series). Autokorelasi ini menunjukkan hubungan antara nilai-nilai yang berurutan dari variabelvariabel yang sama. Uji Autokorelasi bertujuan untuk menilai apakah dalam model regresi linear ada korelasi antara kesalahan penganggu pada periode $t$ dengan kesalahan pengganggu pada periode t-1 (sebelumnya).

Tabel 7. Hasil Autokorelasi

\begin{tabular}{cc}
\hline Model & Durbin-Watson (DW) \\
1 & 1,500 \\
\hline
\end{tabular}

a. Dependent Variable: Y

Sumber: Output SPSS (2018) 
Salah satu ukuran dalam menentukan ada tidaknya masalah autokorelasi dengan Uji Durbin-Watson (DW). Dari Tabel 7, diketahui nilai DW test yang dihasilkan dari model regresi lebih kecil dari $4(1,500<4)$. Dapat disimpulkan, tidak terjadi autokorelasi.

Terkait pengelolaan HD merupakan permasalahan yang esensial dan mendasar, termasuk bagi Pemerintah Kabupaten Berau dan Kampung Merabu. Dalam memberikan pelayanan kepada masyarakat, maupun dalam rangka pembangunan bidang pertanian, kehutanan dan perikanan memerlukan dana operasional. Berdasarkan data dan penjelasan yang telah dikemukakan sebelumnya, maka permasalahan dalam penelitian ini secara garis besar adalah kurangnya bantuan bersifat pendampingan secara berkala, akses pasar, transportasi, jaringan infrastruktur yang memadai, pengembangan SDM, hingga pada keterlibatan, dan partisipasi masyarakat Kampung Merabu yang belum optimal, sehingga harus merujuk pada pembangunan desa yang merupakan bagian dari skala Kabupaten, Provinsi maupun Nasional, agar pembangunan desa ini dapat dilaksanakan secara serasi dan terpadu dalam rangka mewujudkan pembangunan berkelanjutan.

\section{Kesimpulan}

Mengacu pada tujuan penelitian dan model analisis yang digunakan, kesimpulan penelitian ini adalah sebagai berikut: Analisis regresi membuktikan bahwa lama SK diterima dan jumlah tenaga kerja berpengaruh positif terhadap pendapatan petani secara signifikan. Sejak status HD terbit tahun 2014, petani mulai bertransformasi untuk mengelola dan memanfaatkan lahan hutan, yang rata-rata tiap anggota memanfaatkan 2 ha, untuk bercocok tanam atau budi daya ternak. Selanjutnya, jumlah tenaga kerja mengalami kenaikan yang cukup drastis dari sebelum dan setelah SK HD diterima. Ini tercermin dari nilai Chi-Square 239,512 yang signifikan pada derajat 99\%.

Jumlah tenaga kerja merupakan variabel yang berpengaruh dominan terhadap pendapatan petani Kampung Merabu. Kendala yang dihadapi oleh petani kelompok HD adalah kombinasi dari akses pasar, akses modal dan peralatan yang masih tradisional, serta kendala lainnya, seperti: rendahnya, kualitas SDM, sarana tansportasi, dan infrastruktur jalan.

Berdasarkan hasil analisis dan temuan, dapat ditarik implikasi kebijakan dari perspektif ekonomi yaitu: (1) Program pemberian SK HD kepada petani/masyarakat perlu terus dilaksanakan secara berkesinambungan dengan mempercepat pengurusan ijin usaha, termasuk kemudahan, dan kecepatan pemberian ijin yang terkait dengan pengelolaan hutan, luas lahan, serta kesiapan kelompok tani HD; (2) Agar lebih optimal, program perhutanan sosial, khususnya HD harus bekerja sama dan bersinergi dengan pemangku 
Juliansyah Roy, Mudrajad Kuncoro, Dio Caisar Darma

kepentingan, yaitu: pemerintah daerah, akademisi, dunia usaha, komunitas lokal, dan media massa (Penta Helix). Keterlibatan pemangku kepentingan diharapkan dapat meningkatkan hasil produksi, pendapatan petani, penyerapan tenaga kerja, penurunan kemiskinan, dan kemitraan usaha; (3) Sebagian besar responden masih tergolong petani tradisional, maka diperlukan dukungan, bantuan, dan pendampingan terkait dengan akses pasar, akses modal, akses bahan baku, akses terhadap peralatan modern, perbaikan infrastruktur, jaringan telekomunikasi, dan transportasi, serta pemberdayaan SDM.

\section{Daftar Pustaka}

Adilaga, A. 1993. Ilmu Usaha Tani. Alumni Bandung.

Badan Pusat Statistik Berau. 2016 (a). Berau Dalam Angka 2016. BPS Kabupaten Berau. Tanjung Redeb. 2016 (b). Kecamatan Kelay Dalam Angka 2016. BPS Kabupaten Berau. Tanjung Redeb.

Damanik, J. A. 2014. Analisis Faktor-Faktor yang Mempengaruhi Pendapatan Petani Padi di Kecamatan Masaran, Kabupaten Sragen. Economics Development Analysis Journal. Vol. 3(1). Pp. 212-224.

Gujarati, D. 2003. Dasar-Dasar Ekonomerika. Salemba 4. Buku 1 dan 2. Edisi 5. Erlangga. Jakarta.

Kementerian Kehutanan. 2011. Peraturan Menteri Kehutanan Nomor: P/49/Menhut-II/2020/Menhut-II/2011/2010 Tentang Hutan Desa. Sekretariat Negara Republik Indonesia. Jakarta. . 2014. Keputusan Menteri Kehutanan Nomor: 28/Menhut-II/2014 Tentang Penetapan Areal Kerja Hutan Kampung Merabu (Kabupaten Berau). Sekretariat Negara Republik Indonesia. Jakarta.

Kementerian Kehutanan. 2016. Peraturan Menteri Lingkungan Hidup dan Kehutanan Nomor: P. 83/MENLHK/SETJEN/KUM.1/10/2016 Tentang Perhutanan Sosial. Sekretariat Negara Republik Indonesia. Jakarta.

Kuncoro, M. 2013. Metode Riset Untuk Bisnis dan Ekonomi, Bagaimana Meneliti dan Menulis Tesis. Erlangga. Jakarta.

2018. Metode Kuantitatif untuk Bisnis dan Ekonomi. UPP STIM YKPN. Yogyakarta.

Lin, X. Z., \& Ying, N. 2010. Factors Affecting the Income Farmers. Asian Agricultural Research. Vol. 2(5). Pp. 18-26.

Mubyarto. 1990. Pengantar Ekonomi Pertanian. BPFE-UGM. Yogyakarta Pemerintah Kampung Merabu. 2017. Merabu ASIK Aman, Sejahtera, Indah dan Kreatif. Kerjasama Pemerintah Kampung Merabu dengan Patriot Nusantara. Berau. 